\title{
Description of a new species of Pleseobyrsa (Heteroptera: Tingidae) from Costa Rica
}

\section{Descripción de una nueva especie de Pleseobyrsa (Heteroptera: Tingidae) de Costa Rica}

\author{
Sara I. Montemayor ${ }^{1 *}$, Allan González-Herrera ${ }^{2}$ and Keylor Villalobos ${ }^{2}$ \\ ${ }^{1}$ División Entomología, Museo de La Plata, UNLP, Paseo del Bosque, 1900 La Plata, Buenos Aires, Argentina. \\ ${ }^{2}$ Laboratorio de Entomología, Escuela de Ciencias Agrarias, Universidad Nacional de Costa Rica, Apdo. 86-3000, Heredia, Costa Rica. \\ *Correspondent: smontemay@fcnym.unlp.edu.ar
}

\begin{abstract}
Resumen. Se describe una especie nueva de Pleseobyrsa, P. persea n. sp. de Costa Rica, cuya planta huésped es Persea americana P. Mill., siendo ésta la segunda especie del género conocida del país y la tercera cuya planta huésped es P. americana (aguacate). Se describen tanto el adulto como el estadio ninfal V; se agrega una clave modificada de Froeschner para las especies, y se ilustran ejemplares en el campo, el quinto estadio ninfal, adulto y los principales caracteres.

Palabras clave: Tinginae, Pleseobyrsa, especie nueva, ninfa V, Persea americana (Aguacate), América Central.

Abstract. A new Pleseobyrsa, P. persea n. sp. is described for Costa Rica. The host plant of this new species is Persea americana P. Mill. This corresponds to the second species of the genus known for the country and the third whose host plant is $P$. americana (avocado). A description of the adult as well as of instar $\mathrm{V}$ are provided, together with a key to species, photographs taken in the field, and illustrations of the fifth nymph stage, adult, and the main characters.
\end{abstract}

Key words: Tinginae, Pleseabyrsa, new species, instar V, Persea americana (Avocado), Central America.

Introduction

Pleseobyrsa Drake and Poor 1937 belongs to the tribe Tingini and was erected to place 3 species previously assigned to the genus Leptobyrsa Stål 1873 and a new species. After the description of Leptobyrsa 5 other species were described for this genus. Until 1969 Pleseobyrsa was constituted by 9 species, but this year Froeschner described a new genus belonging to the tribe Litadeini Drake and Ruhoff 1965, Stragulotingis Froeschner 1969, to place 2 of the species of Pleseobyrsa. In a later publication (1991) Froeschner transferred 2 other species from Pleseobyrsa to Stragulotingis, described a new Pleseobyrsa and provided a key to the species of both genera. Currently the genus is constituted by 6 species: P. nigriceps (Champion 1897) known from Guatemala and Panama, is the only species exclusively distributed in Central America; P. chiriquensis (Champion 1897) distributed in Costa Rica, Panama,

Recibido: 19 mayo 2010; aceptado: 28 agosto 2010
Colombia and Venezuela and the other 4 species are known from South America. P. ablusa (Drake and Hambleton 1946) and P. peruana (Drake 1939) are distributed in Peru, P. boliviana (Drake and Poor 1937) in Bolivia; and P. nigribasis Froeschner 1991 in Colombia. Two of these species, $P$. boliviana and $P$. chiriquensis, have the avocado tree as the host plant. In the present contribution a new species from Costa Rica is described along with its fifth instar. Photographs in the field, illustrations of the fifth instar, the adult and the diagnostic characters are provided as well as a key to species modified from Froeschner (1991). This species is the second Pleseobyrsa known for Costa Rica, the third whose host plant is the avocado, and the first for which an instar is known.

\section{Materials and methods}

The type material is deposited in the collections of the Museo de La Plata (MLP), Museo de Entomología de la Universidad Nacional (ECA-UNA) and the Instituto de Biología de la UNAM (IBUNAM). Morphological 
characters were observed with an Olympus SZX16 stereomicroscope. Photographs were taken with an Olympus DP20 digital camera. The scales provided in the illustrations and photographs represent 0.5 millimetres. All measurements are given in millimeters.

\section{Description}

Pleseobyrsa persea n. sp. (Figs. 1-5) Table 1.

Head brown; cephalic spines yellowish; occipital spines subhorizontal, slightly incurved, reaching anterior margins of eyes; frontal unpaired spines prorrect; frontal pair of spines converging; rostrum (Fig. 2) reaching posterior half of mesosternum. Antennal segments I, II and III yellowish, with long erect hairs; segment IV except base dark brown with a few long erect hairs alternate with several short semi-decumbent hairs. Bucculae yellowish biseriated. Pronotum yellowish brown; collar slightly produced forward, with 3 rows of areolae; calli reddish brown; lateral carinae absent; median carinae low, with 1 row of areolae long and low; paranota broadly and arcuately produced in front, strongly constricted at the middle and narrow thence to the base, rounded behind, with 4 rows of areolae anteriorly becoming 1 at base, margins with short spines; posterior process abbreviated and rounded behind. Mesosternal laminae (Fig. 2) subparallel, widest towards the middle, metaesternal laminae closed behind. Hemelytra (Figs. 1, 3) yellowish except for a few embrowned veins below the base, broadly rounded at the base as well as the apex, margins with short spines; costal area with 4 rows of irregular areolae; subcostal area wide, subvertical, across widest part with 6 rows of areolae in females, 4 in males; discoidal area with 5 rows of areolae across widest part.

\section{Taxonomic summary}

Holotype.- Female: Alajuela, Llano Bonito de Naranjo, Finca Santa Lucía, $1720 \mathrm{msnm}, 7-\mathrm{I}-2010$, coordenadas: 0786767,1125270 y 0786767,1125270 (UTM 16), en follaje de aguacate variedad Hass, González-Herrera col. (MLP). Paratypes.- 1 female and 2 males: Alajuela, Llano Bonito de Naranjo, Finca Santa Lucía, 1720 msnm, 3-I2000, coordenadas: 0786767,1125270 y 0786767,1125270 (UTM 16), en follaje de aguacate variedad Hass (MLP); 2 males: Alajuela, Llano Bonito de Naranjo, Finca Santa Lucía, 1720 msnm, 3-I-2000, coordenadas: 0786767,1125270 y 0786767,1125270 (UTM 16), en follaje de aguacate variedad Hass (ECA-UNA); 4 females and 2 males: Alajuela, Llano Bonito de Naranjo, Finca Santa Lucía, 1720 msnm, 7-I-2010, coordenadas:
0786767,1125270 y 0786767,1125270 (UTM 16), en follaje de aguacate variedad Hass, González-Herrera col. (ECA-UNA); 1 female and 1 male: Alajuela, Llano Bonito de Naranjo, Finca Santa Lucía, 1720 msnm, 7-I2010, coordenadas: 0786767,1125270 y 0786767,1125270 (UTM 16), en follaje de aguacate variedad Hass, GonzálezHerrera col. (IBUNAM).

Etymology: the specific epithet refers to the host plant (Persea americana) where the holotype was collected.

Host plant: Persea americana var. hass.

\section{Remarks}

The subcostal area is narrower in the males (Fig. 3), where it exhibits 4 rows of areolae across its widest part, whereas in the females (Fig. 1) it has 6 rows of areolae. This kind of dimorphism has already been described in P. nigribasis by Froeschner (1991). Other differences between sexes are the hemelytra shorter and the discoidal area more slender in the males.

The only 2 species of the genus that do not present lateral pronotal carinae are $P$. persea $\mathrm{n}$. sp. and P. nigriceps. Both species are very similar but can be distinguished by characters of the coloration and of the hemelytra. Pleseobyrsa nigriceps has the head, the pronotal calli, and the under part of the body in great part black; the hemelytra have a transverse fascia bellow the base, the veins in the apical half and also those near the base are fuscous and the tip of the tarsi are black (Champion, 1897). Instead $P$. persea has the head, the pronotal calli and the under part of the body brown; the hemelytra also presents a transverse fascia bellow the base but the veins in the apical half and also those near the base are yellowish and the tip of the tarsi are brown. In P. nigriceps the anterior margin of the hemelytra form a acute angle with the longitudinal axis of the body, the costal areolae at the base of the hemelytra are large, the outer row of costal areolae in the anterior half of the area have the same size or are smaller than the areolae of the next row and the subcostal area is rather narrow with 3 rows of areolae. In P. persea (Figs. 1, 3) the anterior margin of the hemelytra form a right angle with the longitudinal axis of the body (Fig. 1a), the costal areolae at the base of the hemelytra are smaller than in $P$. nigriceps (Fig. 1b), the outer row of costal areolae in the anterior half of the area are larger than the areolae of the next row (Fig. $1 \mathrm{c}-\mathrm{d}$ ) and the subcostal area is wider, in the males there are 4 rows of areolae and in the females 6 rows.

Fifth instar (Fig. 4)

Body broad, general color yellowish-brown. Body length: 1.62-1.65-1.70; width: 1.05-1.12-1.15. Antennal segments covered with long, thin setae; I brownish, II and 

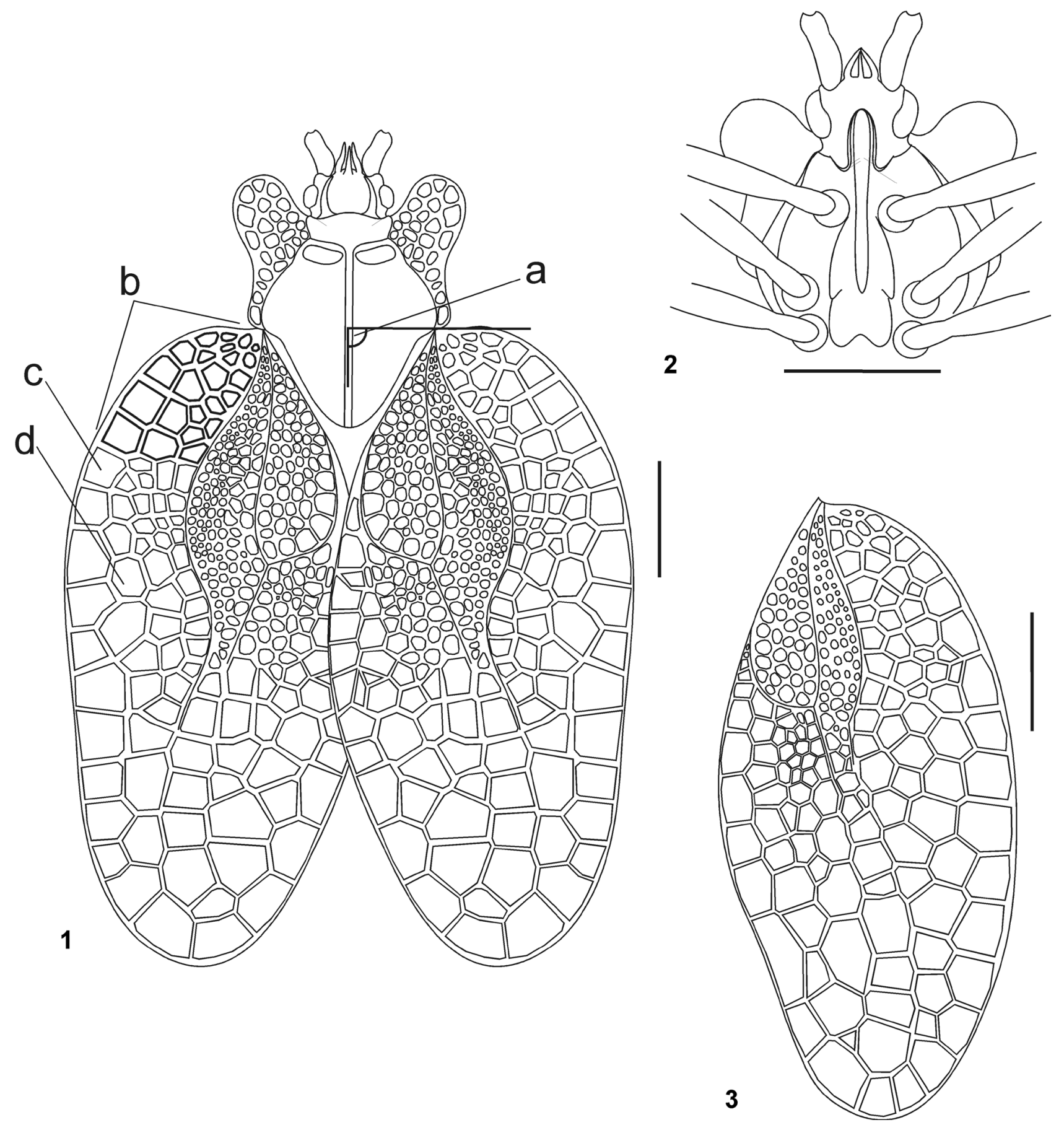

Figures 1-3. 1, Pleseobyrsa persea n. sp. Adult female, dorsal view. a. Angle between anterior margin of hemelytra and longitudinal axis of the body. b. Costal areolae at the base of the hemelytra. c. Outer row of costal areolae. d. Next row of costal arelae. 2 , Pleseobyrsa persea $\mathrm{n}$. sp. Rostrum and rostral laminae, ventral view. 3, Pleseobyrsa persea n. sp. Adult male hemelytra. 


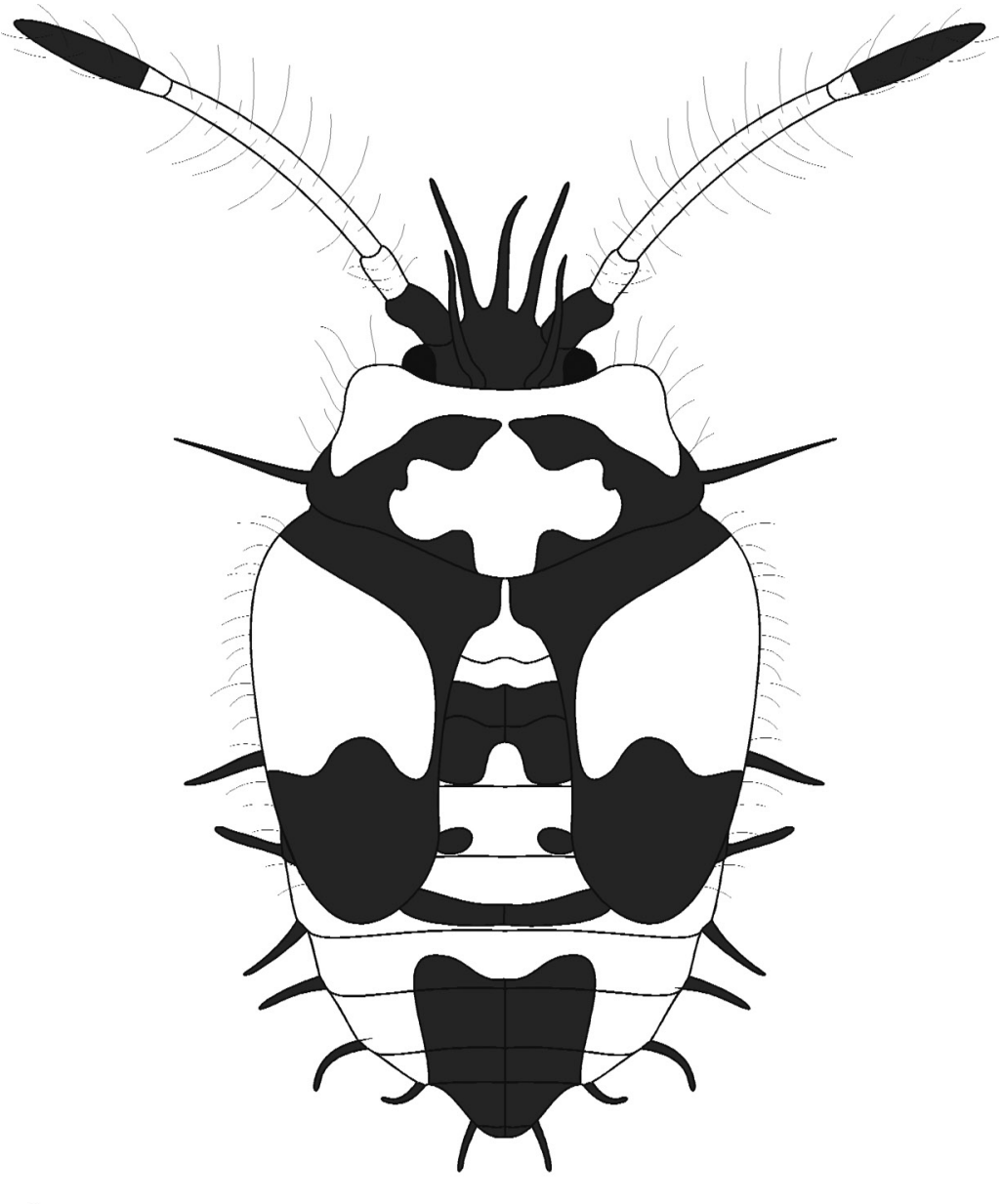

4

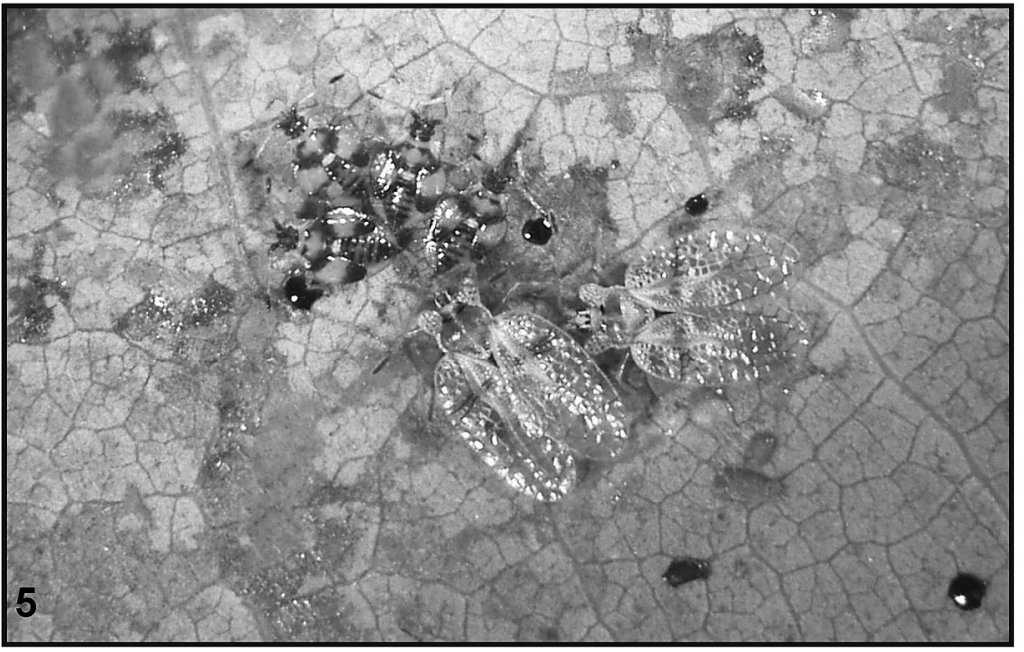

Figures 4-5. 4, Pleseobyrsa persea $\mathrm{n}$. sp. Fifth instar, dorsal view. 5, Pleseobyrsa persea $\mathrm{n}$. sp. Nymphs and adults on leaves of Persea americana. 
III yellowish and IV dark brown except base yellowish. Measurements: I: 0.12-0.12-0.10; II: 0.07-0.07-0.07; III: 0.50-0.52-0.52; IV: 0.35-0.37-0.30. Head brown armed with 5 long thin spines, a frontal pair, a single median and an occipital pair. Frontal and occipital pair of spines divergent; longer than frontal spine. Prothorax dark brown except for the collar, the paranota except posterior third and the sides of the median pronotal carina yellowish brown. Pronotal margins with long and thin setae, lateroposteriorlly with a long stout dark brown spine on each side. Wing pads anteriorly, inner margins and posteriorly dark brown, medially yellowish; outer margins with long and thin setae. Abdominal segments IV, XI and XII dark brown; $\mathrm{V}$ dark brown except medially and posterior edge; VI with 2 dark brown spots; VII with a long transverse dark brown band; segments VIII-X medially dark brown; rest of abdomen yellowish brown. Lateral margins of the last 7 abdominal tergites with a dark brown, simple, long tubercle on the posterior lateral margins.

\section{Taxonomic summary}

Material examined: 3 nymphs. Costa Rica: Alajuela, Llano Bonito de Naranjo, Finca Santa Lucía, 1720 msnm, entre las coordenadas: 0786767,1125270 y 0786767,1125270 (UTM 16), en follaje de aguacate variedad Hass, GonzálezHerrera col. (MLP).

Observations on the host plant. Both nymphs and adults (Fig. 5) cause chlorosis on the leaves where they feed. The leaf tissue acquires light green to yellowish-brown colorations, with necrotic patches. The feeding activities continue up to the death of the tissues and the fall of the leaves, causing great injury to the tree. There are several generations throughout the year, but it is in the summer months when the number of individuals increases.

Key to Pleseobyrsa species (modified from Froeschner, 1991)

1.-Lateral carinae of pronotum absent; occipital spines elongate, decumbent, reaching at least up to middle length of eye $1^{\prime}$.-Lateral carinae of pronotum low but distinct, sometimes present only on anterior slope of interhumeral convexity; occipital spines very short, sometimes tubercle-like, suberect

2.-Head, calli and body beneath in great part black; subcostal area narrow, with 3 rows of areolae.

2 '.-Head, calli and body beneath brown to reddish-brown; subcostal area wide, with 4 (male) or 6 (female) rows of areolae. P. persea n. sp. 3.-Lateral carinae of pronotum extending onto posterior triangular projection of pronotum and nearly or quite reaching middle third of this lateral margin.......................................................................................................... a ablusa $3^{\prime}$.-Lateral carinae of pronotum not extending onto posterior triangular projection of pronotum terminated remotely from its lateral margins. 4.-Medial carina on triangular posterior projection of pronotum slightly elevated with a single row of small but distinct cells extending virtually to its apex. P. boliviana $4^{\prime}$.-Medial carina on triangular posterior projection of pronotum reduced to a low carina without ce ls. 5 5.-Pronotal collar forming a low but distinct tectate anteromedian cyst, latter projecting between occipital spines as a broadly obtuse angle. P. peruana 5 '.-Pronotal collar without a distinct cyst, anterior margin transverse, not projecting 


\section{Acknowledgements}

This work was supported by the Consejo Nacional de Investigaciones Científicas y Técnicas (CONICET) of Argentina and the Vicerrectoría Académica and Dirección de Investigaciones de la Universidad Nacional de Costa Rica.

\section{Literature cited}

Champion, G. C. 1897. Rhynchota (Hemiptera-Heteroptera) Vol. II. In Biologia Centrali-Americana, F.D. Godman and O. Salvin (eds.). London p. 1-32.

Drake, C. J. 1939. Seven new South American Tingitidae (Hemiptera). Revista de Entomología 10:525-530.

Drake, C. J. and E. J. Hambleton. 1946. Three new species and a new genus of American Tingidae (Hemiptera). Entomological News 57:121-125.

Drake, C. J. and M. E. Poor. 1937. Concerning the genus Leptobyrsa Stål (Hemiptera). Proceedings of the Biological Society of Washington 50:163-166.

Drake, C. J. and F. A. Ruhoff. 1965. Lacebugs of the world, a catalog (Hemiptera: Tingidae). United States Museum Bulletin. 243:1-634.

Froeschner, R. C. 1969. Zoogeographic and systematic notes on the lace bug tribe Litadeini, with the description of the new genus Stragulotingis (Hemiptera: Tingidae). The Great Basin Naturalist 29:129-132.

Froeschner, R. C. 1991. The lace bug genera Pleseobyrsa and Stragulotingis: reviews, keys, and description of 1 new species in each (Heteroptera: Tingidae: Tinginae). Proceedings of the Biological Society of Washington 93:767-771.

Stål, C. 1873. Enumeratio Hemipterorum. Köngliga Svenska VetenskapsAkademien Handlingar 11:1-163.

Table 1. Measurements (mm) of Pleseobyrsa persea

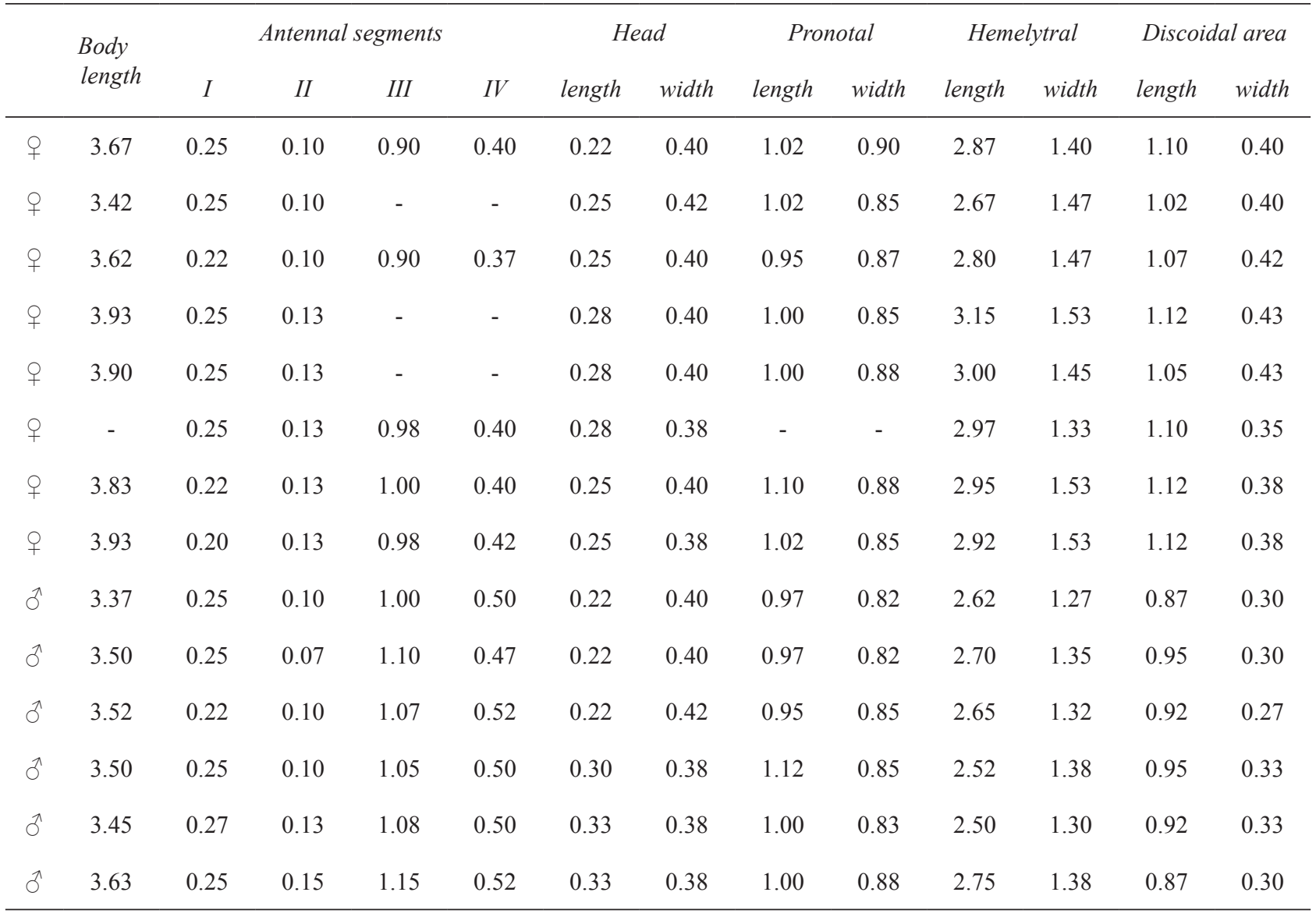

